\title{
Appraisal on the Institutionalization of Human Right Education at Post Primary School Level, Hossaena, Ethiopia
}

\author{
Ephrem Ahadu*; Desta Abebe \\ Department of Civics and Ethical Studies, Wachemo University, Hosaena, Ethiopia \\ *Email: tabiney72@gmail.com
}

http://dx.doi.org/10.18415/ijmmu.v6i5.1142

\begin{abstract}
This research on the institutionalization of human right education at post primary school level was carried out in Hossana town of 4 primary school ( 2 from private and 2 from public school) namely Alemu W/Hanna public school, Hassana Vision academy private primary School, Wachemo public school and FA private school, Ethiopia. The study sample comprised 345 out of the total 2,500 population using Yeman (1967:886) formula. Two types of research questions and one hypothesis were evolved to guide the study. A 10-item questionnaire titled "Human Right Education Questionnaire" was applied for data gathering. The reliability coefficient of the tool using Cronbach Alpha stretched from $0.86-0.96$. Data gathered were examined by means of mean and independent t-test statistical instruments. To remove partiality the data were scrutinized, cross checked and triangulated using different mechanisms. The outcomes of the study exhibited that Human right education has not been institutionalized into the school curriculum, even though human right protection activities and lessons are vital part of the school life. The result of the study also discovered that public and private schools do not differ significantly in the institutionalization of human right education at post primary school level. Based on the finding of the study, it was recommended that activities to enhance human right education should be given due emphasis and encouraged in the school system.
\end{abstract}

Keywords: Human Right; Education; HRE; Institutionalization; Post Primary School; Hossana; Ethiopia

\section{Introduction}

Human rights education (HRE) defined as education, training and information aimed at building a universal culture of human rights through the sharing of knowledge, imparting of skills and moulding of attitudes to prompt action directed at strengthening respect for human rights, fundamental freedoms, tolerance, equality and peace, among individuals, within societies and among nations (UN, 2012). The concept of Human Rights is deep-rooted in freedom of thought and the dignity of human being. "Human Rights" as the term is most commonly used, are the rights, which every human being is entitled to enjoy and to have protected. The underlying idea of such rights- fundamental principles that should be respected in the treatment of all men, women and children- exist in some form in all cultures and societies (Patel, 2010). 
As Human Rights Education (here after HRE) becomes a more common feature of international policy discussions, national textbook reform, and post-conflict educational strategies, greater clarity about what HRE is, does, and means is needed (Bajaj, 2018). Human rights education (HRE) is a newly established field of educational theory and practice that is garnering increased attention and significance across the globe. This effort, which has gained momentum since the early 1990s, has spawned a growing body of educational theory, practice, and re- search that oft en intersects with activities in other fields of educational study in schools, such as citizenship education, peace education, antiracism education, Holocaust/genocide education, education for sustainable development, and education for intercultural understanding. However, HRE is not only aimed at the formal education sector but has deep roots in the non-formal education sector; it also takes place in the training of professionals such as journalists, teachers, and law enforcement officials (F. L. Tibbitts, 2002).

There is a growing consensus amongst the international community that human rights education can contribute to reducing human rights violations and to the creation of a more peaceful and just society (Uddin, 2017). Yet it is still unclear how much schools and education sector of the country considered HRE in their curriculum and institutionalized or not. HRE is explicitly focused on human rights and labelled as human rights education. The speci- ficity of HRE is that it uses human rights as a specific component in teaching and learning. Participants in the learning process use the discourse of human rights for it to be considered as HRE (Ty, 2011). The most widely accepted definition of human rights education (HRE) is that presented by the United Nations, whose General Assembly passed in December 2011 a Declaration on Human Rights Education and Training with the following language (Article 2). According to United Nations General Assembly, Human rights education and training comprises all educational, training, information, awareness- raising and learning activities aimed at promoting universal respect for and observance of all human rights and fundamental freedoms and thus contributing, inter alia, to the prevention of human rights violations and abuses by providing persons with knowledge, skills and understanding and developing their attitudes and behaviors, to empower them to contribute to the building and promotion of a universal culture of human rights.

From the global perspective, a common core of human rights education includes four basic elements: (1) knowledge of the main international human rights documents; (2) the combination of human rights and human duties that emerge out of them as well as the responsibility of the individual towards the community, society and the developing "world society"; (3) knowledge about human rights violations (including all forms of inequality and discrimination; (4) the various forms of resistance, key events and important persons or organizations within the world-wide struggle for human rights (Lohrenscheit, 2004). Human Rights Education has been adopted and elaborated by many countries over the past 20 years. It responds to a perceived need in a community, and the methods of teaching human rights may differ depending on the context. For example, teaching HRE in a private school will certainly differ in its approaches from teaching HRE in a government school (Uddin, 2017).

\section{HRE Framework}

Numerous instructors frequently manage parts of human rights without giving it that name. HRE gives a typical structure through which distinctive topics might be educated in connection to each other. The point of globalization, the earth, peace, citizenship, gender equality, democracy, poverty, and intercultural relations all location human right issues and endeavor to manufacture a culture that regard human rights. Instead of instructing about these subjects matters in seclusion, utilizing a HRE structure gives instructor and understudies a common worth framework through which all subjects meet. 


\section{Diagram: 1 Human Rights Framework}

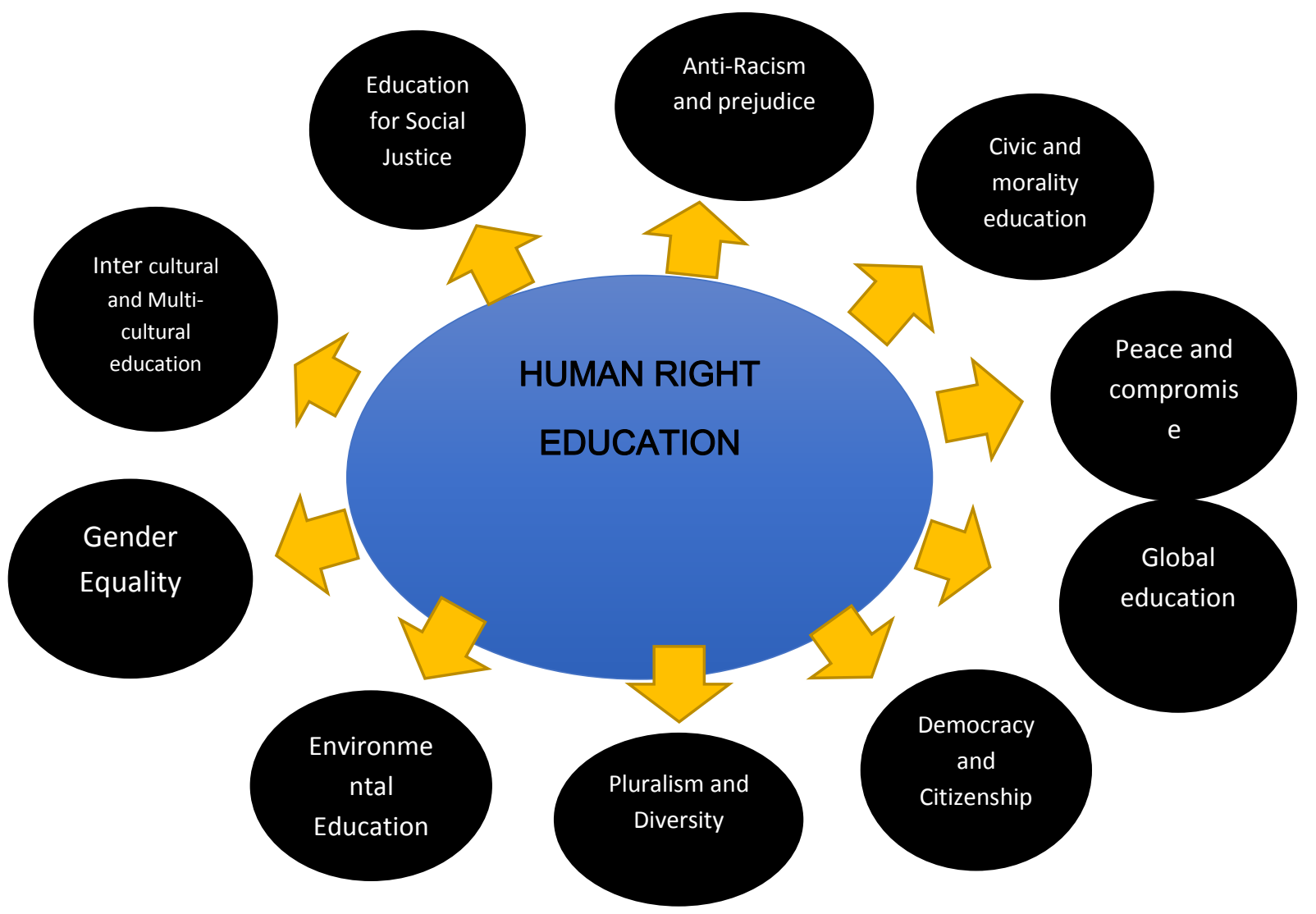

Source: Authors Sketch

There is notable increase in human rights emphases in textbooks in the period since 1994. The change is associated with the rise of more internationalized perspectives and with the relative decline of history in the curriculum (compared with civics and social studies, which have a more universalized flavor). In the most recent period, it seems to be associated with the rising student-centrism of textbooks and curricula (Meyer et al., 2010).

The Ethiopian Constitution (1995), the Education and Training Policy (1994), UN conventions such as the Convention on the Rights of the Child (1989) and other policy documents of the Ethiopian Government clearly indicate that peace, democratic and peaceful society, and human rights and peace education are highly important for the development of Ethiopia (Wondimu, 2017). However, the experiences of countries like Ethiopia in institutionalizing the HRE is remained unexamined. As such, this paper intended to examine to what extent is HRE is institutionalized in the school curriculum? And To what extent is activities of human right institutionalized in the school life? And the research hypothesized that Public and private post primary schools do not differ significantly in the way HRE are institutionalized. A researcher (Lohrenscheit, 2004) found that there are two distinguish basic principles or directions of human rights education: learning about and learning for human rights as it is shown below in table 1 . 
Learning about human rights

rights

$\Rightarrow$ emphasis on:

Knowledge, Understanding, Valuing Solidarity

Contents:

- genesis, history and relevance of human rights documents

transformation of

- controversies and conflicts of

human rights in the int. Debate

- content of the various declarations

the

and conventions

and the

- realisation (instruments) and

practice of human rights

(including national and international

actors)

\section{Learning for human}

$\Rightarrow$ emphasis on:

Respect, Responsibility,

- empowerment

- participation in the

community life and society

- solidarity/"rights of the others"

- tension between adaptation to

established norms of society

resistance and struggle for the

fulfilment of basic rights

Source: Lohrenscheit (2004)

The main area, finding out about human rights, involves learning of the beginning, history and importance of human rights and focal human rights archives just as universally settled instruments for their acknowledgment. Learning and instructing about human rights likewise includes members becoming more acquainted with the various aspects and contentions of the global talk - including the different entertainers on the national and worldwide levels. This methodology is straightforwardly connected to the rudiments of the UDHR as pointed out above. Its accentuation lies in the aggregation of learning and subjective abilities and the understanding and positive esteeming of human rights. All human rights programmes entail this first dimension of HRE, and most of them proceed further to the second dimension: learning for human rights. Here the empowered and active individual is the central goal (Lohrenscheit, 2004).

\section{Statement of the Problem}

Previously researchers such as Patel,(2010),Lohrenscheit (2004) Bajaj,(2018),Cargas, 2019),Cargas \& Mitoma, (2019), F. Tibbitts, (2002), Becker, Wet, \& Vollenhoven, (2015), Ty, (2011), and Wondimu, (2017) expressed their agreement on the crucial contribution of HRE to the realization of human right as well as to the long term avoidance of human right abuse and violent conflict and for fostering a culture of peace in order to enable individuals to live peacefully together.

Recently, in Ethiopia, we are witnessing many violence (terrorism, killing, rapping, kidnapping, displacement) and ethnic conflict (inter and intra) as the notion and valuing of human dignity is dramatically decreasing that endangered the peaceful co-existence of the society. This is against the UDHR provision (article 2 states that "No one shall be subjected to torture or to cruel, inhuman or degrading treatment or punishment"). And it is also in contradict with the FDRE constitution chapter 
three of the constitution in general and article 18 in particular "Everyone has the right to protection against cruel, inhuman or degrading treatment or punishment". In order "to identify and combat all forms of discrimination in schools and society' and 'to confront and overcome prejudices', it is necessary to understand equality issues per se as well as being able to apply them to education (Blair et al., 2003). Even though the young are assumed to be ambassador of peace and pillars of tomorrow paradoxically they are increasingly being used in the wave of violence that has engulfed the country without aware of the result of their actions. Education is often believed as a solution to conflict and violence, especially HRE. This study is conducted to assess the extent to which HRE is institutionalized at the post primary school in Ethiopia.

\section{Research question}

- To what extent is HRE institutionalized in the school curriculum?

- To what extent is Human Right Protection activities institutionalized in the school life?

\section{Hypothesis}

1. There is no as such a big difference in institutionalizing HRE in both Public and private post primary schools.

\section{Methodology}

This paper which concentrated on institutionalization of HRE in post primary schools used a descriptive survey design. The survey design was adopted since it attempts to study the nature of the situation as it exist. The study was carried out in Hossana town, Ethiopia by taking both primary and secondary schools.

Sample size and the sample selection process procedures should assure the representativeness of the total population. After having the total population from the concerned body the total number of sample size determined by applied simplified formula provided by Yemane, (1967:886) A 95\% confidence level and $\mathrm{P}=.05$ as cited in (Israel, 2012).

$$
\begin{aligned}
& n=\frac{\mathrm{N}}{1+\mathrm{N}(\mathrm{e}) 2} \text { Where, } \mathrm{n}=\text { is the sample size } \\
& \mathrm{N}=\text { is the total population } \\
& \mathrm{e}=\text { is have level of precision }
\end{aligned}
$$

The study population covered 2,500 teachers. Out of this, 450 were from private schools while 2,050 were from public schools. Forty percent of the population constituted the sample of the study. Thus a sample of 345 teachers were drawn using stratified sampling technique. Of this, 228 teachers were drawn from public schools while 117 teachers were drawn from private schools. Teachers were used in this study as they are individuals who are assigned explicitly to enforce the curriculum on the ground. The items were organized using 5 types of Likert scale (Agree, Disagree, strongly agree, Strongly Disagree and Neutral). After the sample size was determined in such a way, samples from each schools (both public and private) were selected through stratified sampling method and to determine the sample size from each school, proportional allocation method was used. The research first explored the major types of 
human right education that has been developed by reviewing different former studies conducted by various researchers and international institutions. Accordingly the researcher developed a 19-item questionnaire titled "Human Right Education Questionnaire" was applied for data gathering.

\section{Result and Discussion}

\section{Demographic Characteristics of Respondents}

Demographically, the participants of the research have various social backgrounds. In terms of gender, males were the majority of respondents (82\%) while female accounts $28 \%$ of the participants. In terms of religion, the participants were Protestants (43.2), Orthodox Christians (40.4\%), Muslims (12.2) and others (4.2\%). Regarding to their ethnic background of the respondents Hadiyya (47.2\%), Amhara (26.4\%), Oromo (2.0\%) ,Sidama (11.8\%), Tigre (2.5\%), whereas $10.1 \%$ are choice to say we are Ethiopians rather than specify their ethnic identity and others $(10.3 \%)$.

\section{Results}

Based on our research questions and hypothesis we find the following results.

\section{Research question 1}

To what extent is HRE is institutionalized in the school curriculum?

Table 2: Mean scores (out of 5\%) of HRE as part of the school curriculum

\begin{tabular}{|c|c|c|c|c|}
\hline No. & Questions & Mean & Rank & Remarks \\
\hline 1. & $\begin{array}{l}\text { Student are aware of Human } \\
\text { Rights }\end{array}$ & 3.12 & $1^{\text {st }}$ & Agree \\
\hline 2. & $\begin{array}{l}\text { The syllabuses encourages } \\
\text { civic commitment among } \\
\text { students. }\end{array}$ & 3.00 & $2^{\text {nd }}$ & Agree \\
\hline 3. & $\begin{array}{l}\text { Essay and play competitions } \\
\text { on Human Right are organized } \\
\text { for Students regularly. }\end{array}$ & 2.39 & $3^{\text {rd }}$ & Disagree \\
\hline 4. & $\begin{array}{l}\text { HRE is included in different } \\
\text { subjects as a sub- topic }\end{array}$ & 2.35 & $4^{\text {th }}$ & Disagree \\
\hline 5. & $\begin{array}{l}\text { There are ample books in the } \\
\text { library regarding to Human } \\
\text { Rights }\end{array}$ & 2.28 & $5^{\text {th }}$ & Disagree \\
\hline 6. & $\begin{array}{l}\text { Respect, peaceful coexistence } \\
\text { and Justice are significant } \\
\text { parts of the school subjects. }\end{array}$ & 2.18 & $6^{\text {th }}$ & Disagree \\
\hline 7. & $\begin{array}{l}\text { HRE is given due attention by } \\
\text { government }\end{array}$ & 2.17 & $7^{\text {th }}$ & Disagree \\
\hline 8. & $\begin{array}{l}\text { There are teachers who can } \\
\text { provide the subject (if exist) } \\
\text { HRE }\end{array}$ & 1.98 & $8^{\text {th }}$ & Disagree \\
\hline 9. & $\begin{array}{l}\text { Students are taught about } \\
\text { multiculturalism, tolerance } \\
\text { and respect for human dignity }\end{array}$ & 1.75 & $9^{\text {th }}$ & Disagree \\
\hline 10. & HRE is taught as a subject & 1.89 & $10^{\text {th }}$ & Disagree \\
\hline
\end{tabular}

\section{Source: Authors finding}


From Table 2, results indicate that 2 out of 10 items of peace education as part of the School curriculum had a mean score between 3.12 and 3.00 which is above the acceptance point of 2.50, while the remaining eight question scored below 2.50. The results reveals that peace education is not established as part of the school curriculum.

\section{Research question 2}

To what level is HRE institutionalized as part of the school life?

Table 3:Mean score of Human Right protection activities in the school

\begin{tabular}{|c|c|c|c|c|}
\hline No. & Question & Mean & Rank & Remark \\
\hline 1. & All students are treated equally in the school. & 2.87 & $1^{\mathrm{st}}$ & Agree \\
\hline 2. & $\begin{array}{l}\text { The school strives for students to let them know about } \\
\text { Respect, Responsibility, and Solidarity. }\end{array}$ & 2.49 & $2^{\text {nd }}$ & Agree \\
\hline 3. & $\begin{array}{l}\text { To strengthening of respect human right Inter-ethnic } \\
\text { friendship is given due emphasis among students. }\end{array}$ & 2.25 & $3^{\text {rd }}$ & Agree \\
\hline 4. & $\begin{array}{l}\text { There are extracurricular activities which fosters the idea } \\
\text { of human right protection. }\end{array}$ & 1.87 & $4^{\text {th }}$ & Agree \\
\hline 5. & $\begin{array}{l}\text { Students are given chance to act plays that show } \\
\text { the negative impact of Human Right Violation }\end{array}$ & 1.39 & $5^{\text {th }}$ & Disagree \\
\hline 6. & $\begin{array}{l}\text { Principles and values of Human Right is posted in the } \\
\text { schools compound in visible way. }\end{array}$ & 1.40 & $6^{\text {th }}$ & Disagree \\
\hline 7. & $\begin{array}{l}\text { Guest speakers are invited to the school as part of } \\
\text { extracurricular activities to discuss about Human Right. }\end{array}$ & 1.45 & $7^{\text {th }}$ & Disagree \\
\hline 8. & $\begin{array}{l}\text { Team computation like football game are takes place } \\
\text { regularly to promote Human right and team-building } \\
\text { spirit. }\end{array}$ & 1.35 & $8^{\text {th }}$ & Disagree \\
\hline 9. & $\begin{array}{l}\text { The school organize debates on Human Right related } \\
\text { issues. }\end{array}$ & 1.34 & $9^{\text {th }}$ & Disagree \\
\hline 10. & $\begin{array}{l}\text { There is peace clubs in the school where the values of } \\
\text { Human Right are taught }\end{array}$ & 1.33 & $10^{\text {th }}$ & Disagree \\
\hline
\end{tabular}

Source: Authors finding,2019

The Outcomes of the result indicates (Table 3) that 8 out of the 10 identified Human Right protection activities in the school system scored below 2.50, whereas 2 out of 10 scored beyond 2.50.The finding of the study tells us how much lower the protection of human right, hence much has to been done in order to halve the problem.

\section{Hypothesis I}

Public and private schools do not differ significantly in the institutionalization of Human Right Education. To test this hypothesis independent t-test statistical tool was used. Results are presented in Table 4. 
Table 4:Independent t-test analysis of public and private post primary schools' significant difference in which HRE and Activities for HR protection are institutionalized

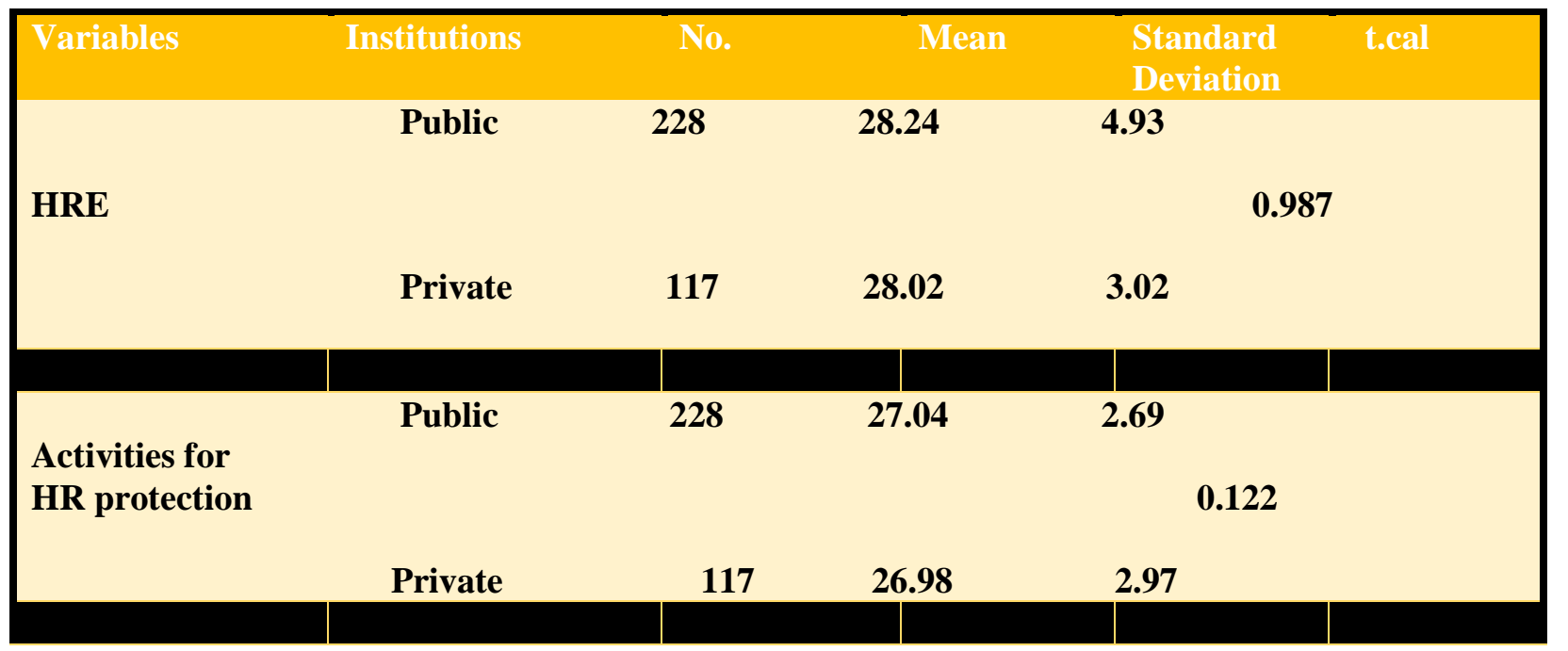

Not significant at $0.05 ; \mathrm{df}=344$; critical t. $=1.975$

Source: Authors finding,2019

As indicated above the results of the study reveals that, the calculated t-value for HRE (0.987) and activities for HR protection (0.122) are both below the critical t-value of 1.975 at 0.05 level of significance with 344 degrees of freedom. This means that in both schools that is public and private post primary do not differ significantly in the way in which HRE is institutionalized. The result of the analysis indicate that the hypothesis was correct and accepted.

\section{Discussion of findings}

From Table 2, results indicate that 2 out of 10 items of peace education as part of the School curriculum had a mean score between 3.12 and 3:00 which is above the acceptance point of 2.50, while the remaining eight question scored below 2.50 .

Results from the research question one showed that eight out of ten identified aspects of HRE as part of the curriculum had a mean score of between 2.39 and 1.89, whereas two out of ten scored between 3.12 up to 3:00 which is above the acceptance level of 2.50 that is Student awareness about Human Rights concept scored 3.21, and syllabuses encourages civic commitment scored 3.00, However the rest eight items scored below 2.50; essay and play competitions on Human Right are organized for Students regularly (2.39), human right education as topics in some school subject (2.35); availability of books in the library related to human rights (2.28); Respect, peaceful coexistence and Justice are significant parts of the school subjects (2.18), HRE is given due attention by government(2.17), regarding to availability of qualified teachers (1.98), Students are taught about multiculturalism, tolerance and respect for human dignity (1.75), and lastly HRE is taught as a subject (1.89).

From the result of the study we can understand that HRE is not given explicitly as a subject and it is not institutionalized as part of the school curriculum. The finding is in line with the study which is conducted by Wirtu,(2018) whose findings indicated that peace education as a theme was not integrated into the functional adult education program of Ethiopia even though there are peace education related concepts. But this research is against the result of Ekpoh, (2015) which is conducted in Nigeria regarding 
to Human Right Education and his finding indicate that peace education has been institutionalized into the school curriculum, although peace culture activities were yet to be made a vital part of the school life and he recommended that activities to enhance peace education and peace culture should be encouraged in the school system. Human rights learning capacitates learners to function as agents of social justice so as to protect and implement human rights, moving to realization to avoid violations, for example, proactive actions to sustain justice (Shultz, 2008). Hence the discovery of this study would like to recommends that formal human right education shall coined into the existing school curriculum of the country.

\section{Conclusion and Recommendation}

\section{Conclusion}

Even though there are some Human Right education related concepts the study revealed that HRE as an independent themes was not encompassed in the country's curriculum framework. Finding of the study indicate that Human Right education is not given independently as a subject in both public and private school and this aggravates conflicts in the country and also increase the vulnerability of the people to continual conflicts that hinder socio-economic growth and cultural transformation. The best types of human rights learning are those that connect with students in the imple-mentation of human rights rules that worry their very own lives. We need to move, to work, and to comprehend, that we move on the planet as free yet capable individuals. The waterway keeps on streaming and we gain our opportunity as human rights ensures us as we move on the planet. However, we as a whole need direction in this honorable journey, we have to figure out how to move along the different backgrounds in nobility while securing the poise of one another. We have to look at the requirements, which we should consider with modesty to evade embarrassment. In this procedure, guided by the human rights system, we will make, ideally, the right choice about the sort of society we need to make for the eventual fate of mankind. We have no other choice

\section{Recommendation}

Human Right education should be given independently as one subject like other subjects.

* In order to foster human right protection activities extracurricular activities play a paramount importance hence strengthening such activities should not be ignored.

* Providing extensive and regular training for teachers about Human Right Education and ways of teaching of human right is also imperative.

\section{References}

Bajaj, M. (2018). Human Rights Education: Ideology, Location, and Approaches. Human Rights Quarterly, 33(2), 481-508. https://doi.org/https://doi.org/10.1353/hrq.2011.0019

Becker, A., Wet, A. De, \& Vollenhoven, W. Van. (2015). Human rights literacy : Moving towards rightsbased education and transformative action through understandings of dignity, equality and freedom. South African Journal of Education, 35(2), 1-12. https://doi.org/10.15700/saje.v35n2a1044 
Blair, M., Ellis, V., Forrest, S., Hatcher, R., Hickey, T., Kelly, J., ... Rieser, R. (2003). Education , Equality and Human Rights Issues of gender, 'race',sexuality,special needs and social class (M. Cole, Ed.). London and New York: Taylor \& Francis Group.

Cargas, S. (2019). Fortifying the future of human rights with human rights education rights education. Journal of Human Rights, 18(3), 293-307. https://doi.org/10.1080/14754835.2019.1617117

Cargas, S., \& Mitoma, G. (2019). Introduction to the special issue on human rights in higher education. Journal of Human Rights, 18(3), 275-279. https://doi.org/10.1080/14754835.2019.1617122

Ekpoh, U. I. (2015). ASSESSING THE INSTITUTIONALIZATION OF PEACE EDUCATION AND PEACE CULTURE AT POST PRIMARY SCHOOL LEVEL IN CALABAR EDUCATION ZONE, CROSS RIVER STATE, NIGERIA. International Journal of Education and Research, 3(7), 175182.

Israel, G. D. (2012). Determining Sample Size 1. 1-5.

Lohrenscheit, C. (2004). INTERNATIONAL APPROACHES IN HUMAN RIGHTS EDUCATION Foundations for Human Rights Education in international declarations and conventions In 1998 , when the United Nations celebrated the 50th birthday of the International Declaration of Human Rights ( 1948. International Review of Education, 48(3-4), 173-185.

Meyer, J. W., Bromley, P., Ramirez, F. O., Meyer, J. W., Bromley, P., \& Ramirez, F. O. (2010). Human Rights in Social Science Textbooks: Cross-national Analyses, 1970 2008. Sociology of Education, 83(2), 112-134. https://doi.org/10.1177/0038040710367936.

Patel, J. V. (2010). Human Rights Education. Educational Journal, 8(11-12), 1-13.

Shultz, A. Aa. and L. (Ed.). (2008). Educating for HUMAN RIGHTS and GLOBAL CITIZENSHIP. United State of America: STATE UNIVERSITY OF NEW YORK PRESS,ALBANY.

Tibbitts, F. (2002). UNDERSTANDING WHAT WE DO : EMERGING MODELS FOR HUMAN RIGHTS EDUCATION Human rights education as an emerging field of inquiry Over the last 12 years, the term " human rights education" ( HRE ) has slipped into the language of Ministries of Education, ed. International Review of Education, 48(4), 159-171.

Tibbitts, F. L. (2002). Evolution of Human Rights Education Models. Newcastle University.

Ty, R. (2011). Social injustice, human rights-based education and citizens' direct action to promote social transformation in the Philippines. Education, Citizenship and Social Justice, 6(3), 204-221. https://doi.org/10.1177/1746197911417413.

Uddin, S. (2017). Human Rights Education for Bengali Women: Agency and empowerment.

UN. (2012). Human Rights Education in Primary and Secondary School Systems: A Self-assessment Guide for Governments.

Wirtu, D. (2018). Peace Education: A Missing Link in the Adult Education Sub-sector of Ethiopia? Ethiopian Journal of the Social Sciences and Humanities (EJOSSAH), XIV.XIV(1), 1-22. https://doi.org/https://dx.doi.org/10.4314/ejossah.v14i1.2. 
Wondimu, H. (2017). 159 Civics and Ethical Education: Student Textbooks (9. The Ethiopian Journal of Education, XXXVI(2), 159-170.

\section{Books}

Blair, M., Ellis, V., Forrest, S., Hatcher, R., Hickey, T., Kelly, J., ... Rieser, R. (2003). Education , Equality and Human Rights Issues of gender, 'race',sexuality,special needs and social class (M. Cole, ed.). London and New York: Taylor \& Francis Group.

Shultz, A. Aa. and L. (Ed.). (2008). Educating for HUMAN RIGHTS and GLOBAL CITIZENSHIP. United State of America: STATE UNIVERSITY OF NEW YORK PRESS,ALBANY.

\section{Acronyms}

- FDRE-Federal Democratic Republic of Ethiopia

- HR-Human Right

- HRE- Human Right Education

- UDHR - Universal Declaration of Human Rights

\section{Constitution and declaration}

Constitution of the federal democratic republic of Ethiopia (1995).Federal Negarit Gazetta. Proclamation number 1/1995

$>\quad$ Universal Declaration of Human Rights

\section{Copyrights}

Copyright for this article is retained by the author(s), with first publication rights granted to the journal.

This is an open-access article distributed under the terms and conditions of the Creative Commons Attribution license (http://creativecommons.org/licenses/by/4.0/). 